Crop Breeding and Applied Biotechnology S2: 1-6, 2012

Brazilian Society of Plant Breeding. Printed in Brazil

\title{
ARTICLE
}

\section{Contribution of graduate programs in plant breeding to the education of plant breeders in Brazil}

Isaias Olívio Geraldi ${ }^{1 *}$

Received 15 September 2012

Accepted 03 October 2012

\begin{abstract}
The success of agribusiness in Brazil in recent decades is unquestionable. Although the country has always had favorable conditions for agriculture (land, water and climate), this success has only come about recently, due to scientific research, which has resulted in considerable increases in yield and in improvement of product quality, as well as making the occupation of new agricultural frontiers possible. A decisive factor for development of agriculture in the country was the creation of EMBRAPA in 1973, which, in a few years, led to considerable demand for researchers with training in graduate programs. Among them are plant breeders, who came to exercise their activity throughout the country and in all ecosystems. The training of plant breeders was only possible because, as from the middle of the 1960s, the country began a wide-ranging education program, with the creation of several graduate programs in genetics and plant breeding.
\end{abstract}

Key words: Plant breeding education, plant breeding training.

\section{INTRODUCTION}

Brazil has taken a quantitative and qualitative leap in the crop and livestock area in the last three decades, such that agribusiness currently has a distinctive role in the GDP (Gross Domestic Product) of the country. This evolution in agribusiness has drawn the attention of many countries and, according to the FAO (Food and Agriculture Organization), Brazil is one of the countries with greatest potential for meeting the world demand for food in the 21st Century. Evidently, a positive factor of the country is its large territorial area and, consequently, availability of land suited to agriculture. But this, evidently, has not been the only factor responsible for the great advance of agribusiness. Domestic crop and livestock production was only able to develop due to scientific research that allowed increases in yield and product quality, as well as the occupation of areas previously considered unsuitable for agriculture, as is the case of the cerrados (tropical savanna region). One of the most important factor for the agricultural development in the country was the creation of EMBRAPA (Brazilian Corporation for Agricultural Research) in 1973 since, up until then, scientific research in crop and livestock raising was concentrated in few institutions and regions of the country and, therefore, without consideration for all the ecosystems and the large extension of national territory. However, research was only possible because the country began a wideranging education program at graduation level in agricultural sciences as from the middle of the 1960s, with the creation of graduate programs in several areas. Among these areas is genetics and plant breeding. In this study, the contributions of graduate programs in Genetics and Plant Breeding for the education of plant breeders in the country will be discussed.

\section{DOMESTIC AGRICULTURE AND PLANT BREEDING}

\section{Research in plant breeding in the country and the beginning of graduate programs}

Historically, Brazil was always considered to be a country of great agricultural potential, and this was due, among other factors, to the breadth of its territory, the existence of abundant water and tropical conditions in most of its territory, with allows more than one crop season per year. Among the countries of large territorial extension, few have such favorable conditions, either through being located in temperate climate regions, that is, with rigorous winters, as is the case of Canada, or through having immense mountainous or desert areas, as is the case of China and of Australia and, therefore, unsuitable for agriculture. In spite

ESALQ/USP, Departamento de Genética, C. P. 83, 13.400-970, Piracicaba, SP, Brazil. *E-mail: iogerald@usp.br 
of that, Brazil took more than four centuries to really take advantage of this great potential.

The development of agriculture, like other areas, depends on scientific research. Agricultural research in Brazil started in the 20th Century, and some facts were decisive for its development: the creation of the first Schools of Agriculture (Colleges of Agriculture) at the end of the 19th and beginning of the 20th Century and, mainly, the creation of the Agronomy Institute of Campinas (IAC) in 1887. The IAC, without a doubt, made a great contribution to agricultural research. For example, the success of coffee growing in São Paulo in the 20th Century occurred due to the contributions of research carried out at IAC (Azevedo 2004, Ramalho et al. 2010, Carbonell et al. 2012). However, because IAC was a state research institute, it was focused on problems of the state of São Paulo. In regard to the Schools of Agriculture, it is important to highlight that they were initially directed more toward teaching than toward research. There was the beginning of some research in them, but it arose more from individual initiatives than university policy. Some faculty refused to do research based on the argument that this would lead to losses in the quality of their teaching. In addition, in many schools, full-time positions had not yet been established which is fundamental for the faculty to have time and conditions for dedicating themselves to research. IAC itself faced many problems due to changes in public policy throughout the 20th Century (Azevedo 2004).

In the specific case of plant breeding, it is important to remember that genetics is a science that arose in the 20th Century and, for that reason, plant breeding gained strength only as from the 1920s, mainly in the United States of America. In Brazil the first initiatives occurred in the 1930s and, as from the 1940s, there were already great advances in agriculture in the country with the release of new cultivars of rice, coffee, sugarcane, vegetables, corn, wheat and other crops. According to Vencovsky and Ramalho (2006) these researches were carried out mainly at the IAC and at the "Luiz de Queiroz" College of Agriculture (ESALQ/USP). It is important to emphasize that the beginning of research in plant breeding in these institutions occurred due to the presence of foreign researchers in Brazil. However, the number of researchers in the country was small and opportunities for training were scarce because there were still no graduate programs. Thus, before the 1960s, Brazilian researchers had the graduate programs of Europe and of the United States as a training option, especially the latter. Consequently, the number of professionals trained was very small and did not meet the needs and different ecological conditions of the country because the few existing researchers were concentrated in the Southeast and South regions (Azevedo 2004).
In 1964, the first graduate program in Genetics and Plant Breeding in Brazil was created at ESALQ/USP. In the first years, the groups of students were small and mainly composed of faculty members from other Universities, such as UNESP (State University of Sao Paulo), UFLA (Federal University of Lavras), UFV (Federal University of Viçosa), UFPR (Federal University of Paraná), UFPEL (Federal University of Pelotas), and UFSM (Federal University of Santa Maria), and also by researchers from other Latin American countries such as Argentina, Chile, Uruguay, Paraguay, Colombia, Venezuela, Peru, Ecuador, Mexico and Panama. Subsequently, three more graduate programs in Plant Breeding were created in other Universities, in the following order (Geraldi 2007): UFV (1976), UNESP/Jaboticabal (1985) and UFLA (1986). Many faculty members of these universities were former students of the ESALQ program. They, for their part, contributed to the education of faculty that created graduate programs in other Universities, and so plant-breeding faculty increased in the country.

As from the middle of the 1970 s, there was a large demand for graduate studies level in all areas of agricultural sciences and, consequently, accentuated growth in the number of students, due, among other reasons, to the creation of EMBRAPA. Part of these students obtained training abroad, but most were trained in Brazil, and this was possible because there were already several graduate programs, not only in Genetics and Plant Breeding, but also in other areas of the agricultural sciences (Ramalho 2004). Without a doubt, the policy adopted by EMBRAPA of giving priority to training of researchers in graduate programs was an important decision and perhaps one of the best public investments in the country. In a few years, the number of researchers with Master's and Doctor's degrees in Agricultural Sciences grew considerably, and was able to meet internal needs. In addition, at that time (the 1970s), the importance of graduate level training was disseminated in the country, so the students from undergraduate courses came to perceive the importance of seeking graduate studies to be able to exercise teaching and research activities in the future. Currently, opening positions for teachers and researchers at Universities and Public Research Institutes require the doctor's degree, something which could not have been done around 30 years ago. In addition, many seed companies also require a doctor's degree in hiring professionals.

The creation of graduate programs in Brazil therefore allowed more people to enroll in graduate studies courses (Azevedo 2004, Demétrio and Vieira 2004) and, consequently, domestic agriculture made a great leap. For example, in the last 30 years, with practically the same area, 
grain production in the country grew from 50 million to 150 million tons (Ramalho et al. 2010). It is also important to emphasize the participation of private seed companies, which occurred after approval of the Variety Protection Law in 1997.

\section{Plant breeders educated in graduate programs}

Graduate programs in plant breeding began in Brazil in 1964, at ESALQ/USP (Table 1). In the two subsequent decades, three more programs were created, all based in the Southeast (SP and MG states) region. Finally in the last 10 years, five more programs have been created. One may therefore observe the existence of two groups: the first, composed of four programs, created between the 1960s and the 1980s, and the last, composed of five programs, created as from 2002. Up to 2011, these programs have granted degrees to 1,606 masters and 891 doctors, for a total, therefore, of 2,497 degrees (Table 1). Evidently, the great majority of doctors come from former master's students of the same graduate programs. More detailed analysis of this table reveals that $85 \%$ of the masters and $94 \%$ of the doctors were educated by the four oldest programs (ESALQ/USP, UFV, UFLA and UNESP/Jaboticabal), which is not surprising, since the programs generally begin with few students and, furthermore, only after some years grant degrees to the first students.

There is, however, an important fact to be considered. The graduate programs in genetics and plant breeding do not educate only plant breeders, but also students trained in cytogenetics, microbial genetics, biotechnology, molecular genetics, etc. who have, without a doubt, great importance. But they will not work as plant breeders, since most of them come from undergraduate courses in other areas, like Biological Sciences, Biochemistry, and Botany, and, therefore, they generally do not have enough knowledge of agriculture. Therefore, the numbers mentioned above are certainly overestimated. In addition, the proportion of plant breeders educated in the programs changes over time. Certainly the proportion of plant breeders was greater at the beginning of graduate programs in genetics and plant breeding. In the last two decades, with the rapid advances in genetics and molecular biology, this proportion decreased in most of the programs.

In a very interesting survey of the theses and dissertations of the graduate programs in genetics and plant breeding in Brazil, from 2002 to 2009 , it was observed that only $26.5 \%$ were really focused on plant breeding (Ramalho et al. 2010). This is a very relevant piece of information since it is based on the final work (thesis or dissertation) of the former student and not on the name of the graduate program where the degree was obtained or on the indication of researcher on his/her résumé, which does not always reflect reality. Considering that in periods prior to this, the proportion of theses or dissertations in plant breeding was greater, one may speculate something around $35 \%$; that is, on average, $35 \%$ of the students of graduate programs in genetics and plant breeding received specific training in plant breeding. This reduces the previously mentioned number to something around 560 masters and 310 doctors; that is, the country educated around 900 plant breeders, between masters and doctors, in the nine programs considered (Table 1). As a large part of the doctors originate from master's programs of the same institutions considered, these numbers overlap, and it is difficult to determine the magnitude of this overlap. However, currently, a graduate student generally does not complete only the master's degree and, therefore, most professionals have the doctor's degree. It may thus be inferred that the country educated at least 310 plant breeding doctorate holders.

Table 1. Graduate programs in Plant Breeding in Brazil, year of creation, number of students granted degrees up to 2011, for master's (M) and doctor's (D) degrees, and Major

\begin{tabular}{|c|c|c|c|c|c|}
\hline University & Year $(\mathrm{M})$ & Year (D) & Degrees Granted (M) & Degrees Granted (D) & Major $^{1}$ \\
\hline USP/ESALQ & 1964 & 1970 & 444 & 402 & GPB \\
\hline UFV & 1976 & 1979 & 435 & 248 & GB \\
\hline UFLA & 1986 & 1995 & 258 & 104 & GPB \\
\hline UEM & 2002 & 2005 & 112 & 28 & GB \\
\hline UFPI & 2009 & - & 13 & 0 & GB \\
\hline UFG & 2010 & 2010 & 12 & 0 & GPB \\
\hline Total & - & - & 1,606 & 891 & \\
\hline
\end{tabular}

${ }^{1}$ GPB: Genetics and Plant Breeding; GB: Genetics and Breeding; PB: Plant Breeding 
On the other hand, several Graduate Programs in Crop Science (denominated Agronomy, Plant Science or Plant Production) have plant breeders in the faculty and consequently also do research and advise students in Plant Breeding. Among these, the programs of the following Universities may be mentioned: UFV, UFRGS (Federal University of Rio Grande do Sul), UFPEL, UFG (Federal University of Goiás), UEM (State University of Maringa), UNESP/Botucatu, UNESP/Ilha Solteira, etc. The first three are quite old and have granted degrees to a reasonable number of plant breeders. The Crop Science program of Viçosa (UFV) is the oldest in the country, having been created in 1961, while that of the UFRGS was created in 1965. Some Graduate Programs in Plant Genetic Resources also have research in Plant Breeding and, among them, the UFSC (Federal University of Santa Catarina) stands out, the oldest of the country within the Agrarian Sciences area of CAPES.

Obviously, it is difficult to obtain information on all the Crop Science programs of the country, i.e., how many plant breeders they have trained, because the number of programs is very large (around 80). But all this indicates that more doctors were educated in plant breeding than previously indicated (310). One may imagine somewhere around 450 to 500 plant breeders with doctor's degree, trained in the Plant Breeding and Crop Science graduate programs in the country. The plant breeders that got their doctorate abroad must also be taken into consideration, but this number is not available. At any rate, we can thus come to an approximate value of the number of plant breeders with doctor's degree in the last 40 years in the country, which should be between 500 and 600 .

However, one must consider that around $25 \%$ of the plant breeders of the country already have more than 30 years of activity and have therefore fulfilled the requirements for retirement, and may come to retire at any time (Ramalho et al. 2010). In fact, many researchers have already retired, as has occurred in recent years at EMBRAPA. According to Bliss (2007) there was at that time around 350 plant breeders in activity in Brazil, of which $95 \%$ were in the public sector and only 5\% in the private sector, a number which is in agreement with the data gathered in this study.

\section{Demand for plant breeders in the country}

Considering now the destination of the plant breeders educated in Brazilian graduate programs, it may be asked if they are working as plant breeders. As has already been mentioned, in the beginning, the few graduate programs principally met the needs of other Universities, some Public Research Institutes, few seed companies and foreign researchers, arising mainly from Latin American countries. Subsequently, the recently-created EMBRAPA hired a great number of the researchers, which occurs even until now, so most of plant breeders in the country is at EMBRAPA (Bliss 2007, Ramalho et al. 2010), followed by Federal and State Universities (Ramalho et al. 2010). As from the beginning of the 21 st century, a great number of students were also hired by the foreign seed companies that established themselves in the country following the Variety Protection Law of 1997.

Currently, all these sectors are hiring students coming from graduate programs. An important question is whether the number of plant breeders educated annually is sufficient for meeting the needs of all these sectors. It may be said that it was sufficient around 10 or 15 years ago, but not currently. There has been a great demand for plant breeders with doctor's degree (often only with a master's degree) by seed companies and for that reason a great number of students from Brazilian graduate programs have been hired even before completing all requirements for the doctor's degree. As a result, there is always several students from doctorate programs that move on to post-doctorate work; mainly those trained in areas like biotechnology, molecular genetics, and cytogenetics, but not in plant breeding. In fact, there is a large demand for plant breeders and, for that reason there has also been a great deal of mobility of qualified plant breeders, mainly from seed companies to Universities or from seed companies to EMBRAPA.

\section{Future perspectives}

The aforementioned facts and the information obtained from the graduate programs in Genetics and Plant Breeding of several Universities in Brazil indicate that the training of plant breeders is not meeting the growth in demand due to two main factors: a) the number of graduate programs in Plant Breeding is still small; and b) the faculty qualified for training in plant breeding in many programs decreased, or is facing reduction.

In regard to the first item, although the number of graduate programs has grown in the last decade, growth is still not sufficient to meet the demand for new qualified professionals. For comparison, from 1995 to 2000 there were plant breeding graduate programs in 40 US Universities (Ransom et al. 2006). The number of programs in Brazil currently (nine) is only $23 \%$ of that, and some of them, moreover, are very new. The comparison with the US graduate programs makes sense because the two countries have similar territorial dimensions and, although US agricultural production is greater, Brazil is distinguishing itself as one of the major food producers, with a large tendency for growth. In this 
context, considering only corn breeders, their number in the USA ranged from 250 to 550 in the period from 1980 to 1990 , while in Brazil, this number was less than $10 \%$ of that in the same period, and, moreover, a relatively lower in other species (Ramalho 2004).

The second item is perhaps of greatest concern. As discussed above, with the advent of new technologies for DNA manipulation in the last 20 years, there has been the need for hiring faculty to meet this new demand, mainly related to Biology and Molecular Genetics. Besides in several Universities, part of the plant breeding faculty have retired or, at least, have completed the requirements and are able to retire at any time. Once more, the example of the United States serves as a warning. In that country, the environment in which many plant breeders were educated has fundamentally changed. At many universities, retiring plant-breeding faculty is not being replaced. Instead, these positions are being replaced by molecularly oriented faculty that can attract large grants in federal sponsoring agencies and publish high-profile papers (Bliss 2006, Lee and Dudley 2006, Hancock 2006, Ramalho et al. 2010). Consequently, the number of academic plant breeders has been on a slow and steady decline and this will probably compromise the training of plant breeders in that country (Lee and Dudley 2006).

Naturally, the question arises as to whether this same process is at work in Brazil. We could say that probably so. There is no intention of discrediting the importance of emerging areas, and besides, they contribute to the training that plant breeders must have in the future. However, the growing of a new area should not be done in detriment to the others. With the decrease in the plant-breeding faculty and the closing of their research programs, there also begins to be a decrease in the faculty able to offer courses that are very important for the training of plant breeders, such as Plant Breeding Methods, Quantitative Genetics, Population Genetics, Statistics, Experimental and Genetic Designs (Bliss 2006, Lee and Dudley 2006). It has also been observed that many times recently-hired plant-breeding faculty start a research program that can be carried out in laboratory due to the pressure they undergo to publish high-profile papers in a short time, and also due to the difficulties to carry out field activities, fundamental for training of plant breeders, but which require many facilities, which the University does not always have (Hancock 2006, Ramalho et al. 2010).

\section{FINAL CONSIDERATIONS}

The purpose of this study was to show the contribution of the Brazilian Universities and particularly of the graduate programs in Genetics and Plant Breeding for the training of plant breeders that have come to work in the Public and Private sectors in the last 40 years. This has allowed the country to experience extraordinary growth in agribusiness, making it, in several cases, a worldwide reference in crop and livestock research. There are many examples of this success (Ramalho et al. 2010), and it is not necessary to repeat them. As shown before, in this period, several hundred researchers who were active and continue to act in the Universities and in the Public and Private Research Institutes were trained. The importance of this is quite clear for the professors and researchers, i.e., within the scientific community, but not for the general society. That is because Universities generally do not carry out advertising. For comparison, the contribution of EMBRAPA to agribusiness is greatly discussed, as it can frequently be seen in the media. But that occurs because EMBRAPA disseminates their technologies very well. Universities should follow this example by disseminating their main product, that is, the plant breeders trained, and how they are contributing to the well-being of society. This is extremely important, and may even affect the decisions of the sponsoring agencies. Unfortunately most people in Brazil still think that faculty in Universities only exercise teaching activities.

These data and data from other studies (Lee and Dudley 2006, Geraldi 2007, Ramalho et al. 2010) also draw attention to a situation which raises concern, which is the future of graduate programs in Plant Breeding, whose faculty are not able to meet the demand for training of plant breeders. It would be very important if the Universities that have already graduate programs in Crop Science and with plant breeders in the faculty, to strive to create graduate programs in Plant Breeding. This option was followed by the State University of Maringá (UEM) in 2002 and by the Federal University of Goiás (UFG) in 2010, among others. Certainly other Universities could do so since there are nearly 80 graduate programs in Crop Science in Brazil. Alternatively, Universities could encourage plant-breeding faculty of the Crop Science programs, to advise students in Plant Breeding programs, as occurs for example at UFLA and at UFV. In short, any action for the purpose of increasing the number of faculty who will train future plant breeders is worthwhile, given the great importance of the area and the growing demand for these professionals.

To get around this kind of problem, in the USA, the participation of seed companies in the education of plant breeders was suggested, through financing of thesis research and also through carrying out this research on company facilities (Lee and Dudley 2006). It would probably be more difficult in Brazil due to the greater distancing between 
Universities and seed companies, for unknown reasons. Some companies have not even provided routine information, such as the number of plant breeders, when requested (Ramalho et al. 2010). Nevertheless, there is the alternative of association with EMBRAPA, which has already signed a cooperation agreement with CAPES such that its researchers can teach and advise students in graduate programs. This cooperation agreement, moreover, foresees the creation of programs in a University-EMBRAPA partnership. This alternative, obviously, is only possible for those Universities that are near some EMBRAPA research center. It is, at any rate, a promising alternative given that EMBRAPA has all the facilities for carrying out field research and also laboratory facilities. This model has already been adopted by the Graduate Program in Genetics and Breeding of the Federal University of Piaui (UFPI).

\section{ACKNOWLEDGEMENTS}

To the coordinators of the Graduate Programs in Plant Breeding and Plant Genetic Resources of the following Universities: UEFS, UEM, UENF, UFG, UFLA, UFPI, UFRB, UFRPE, UFSC, UFV, UNESP/Jaboticabal and USP, for providing information on graduate students.

\section{Contribuição da pós-graduação em genética e melhoramento de plantas na formação de melhoristas}

Resumo - É inquestionável o sucesso do agronegócio no Brasil nas últimas décadas. Apesar das condições favoráveis que o país sempre teve para a agricultura (terra, água e clima), este sucesso só aconteceu recentemente devido às pesquisas científicas, que resultaram em aumentos consideráveis de produtividade e em melhoria da qualidade dos produtos, bem como possibilitaram a ocupação de novas fronteiras agricolas. Um fator decisivo para o desenvolvimento da agricultura do país foi a criação da EMBRAPA em 1973, que resultou, em poucos anos, em demanda considerável de pesquisadores com treinamento de pós-graduação. Entre estes, os melhoristas de plantas, que passaram a atuar em todo o território nacional e em todos os ecossistemas. A formação dos melhoristas de plantas só foi possivel porque o país iniciou, a partir da década de 1970, um programa abrangente de formação de recursos humanos, com a criação de diversos programas de pós-graduação em genética e melhoramento de plantas.

Palavras-chave: Formação de recursos humanos, educação superior, treinamento de melhoristas de plantas.

\section{REFERENCES}

Azevedo JL (2004) A ESALQ: sua inclusão na USP e sua contribuição para a pesquisa em ciências agrárias. Revista USP 60: 14-39.

Bliss FA (2006) Plant breeding in the US private sector. HortScience 41: $45-47$

Bliss FA (2007) Education and preparation of plant breeders for careers in global crop improvement. Crop Science 47: 250-261.

Carbonell SAM, Guerreiro Filho O and Siqueira WJ (2012) Contributions of the Instituto Agronômico (IAC) for plant breeding. Crop Breeding and Applied Biotechnology S2: 15-24.

Demétrio CGB and Vieira MLC (2004) A pós-graduação da ESALQ: 40 anos de história. ESALQ/USP, Piracicaba, 220p.

Geraldi IO (2007) A pós-graduação em genética e melhoramento de plantas no Brasil: diagnóstico e prioridades. Revista Brasileira de Pós-Graduação 7: 87-98.
Hancock JF (2006) Who will train plant breeders in the US and around the world? HortScience 41: 28-29.

Lee EA and Dudley JW (2006) Plant breeding education. In Lamkey KR and Lee M (ed.) Plant breeding: the Arnel R Hallauer international symposium. Blackwell, Ames, p. 120-126.

Ramalho MAP (2004) Genetic improvement and agribusiness in Brazil. Crop Breeding and Applied Biotechnology 4: 127-134.

Ramalho MAP, Toledo FHRB and Souza JC (2010) Melhoramento genético de plantas no Brasil. In Ramalho MAP, Toledo FHRB, Souza JC and Teixeira RA (eds.) Competências em melhoramento genético de plantas no Brasil. Arka, Viçosa, p. 15-38.

Ransom C, Drake C, Particka C and Olmstead J (2006) What kind of training do plant breeders need, and how can we most effectively provide that training? HortScience 41: 53-54

Vencovsky R and Ramalho MAP (2006) Contribuições do melhoramento genético no Brasil. In Paterniani E (ed.) Ciência, agricultura e sociedade. Embrapa, Brasília, p. 57-90. 